
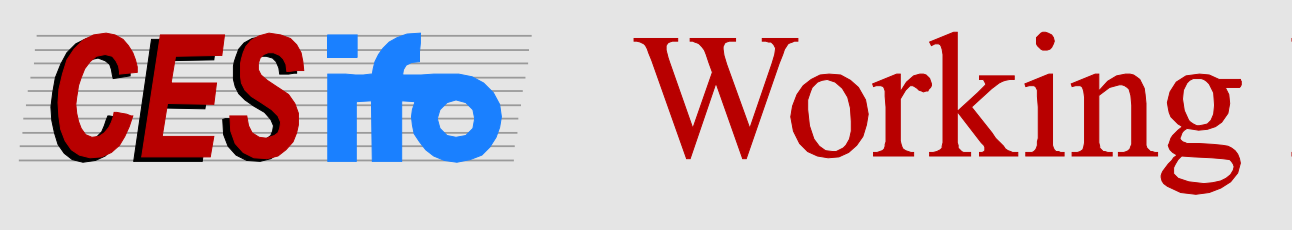

Papers

www.cesifo.org/wp

\title{
Quantifying the Economic Effects of an EU-Japan Free Trade Agreement
}

\author{
Sebastian Benz \\ Erdal Yalcin
}

CESIFO WORKING PAPER NO. 4319

CATEgORY 8: TRAdE POLICY

JULY 2013

An electronic version of the paper may be downloaded

- from the SSRN website:

- from the RePEc website:

- from the CESifo website:

WWW.SSRN.com

www.RePEc.org

www.CESifo-group.org/wp

\section{CESifo}




\title{
Quantifying the Economic Effects of an EU-Japan Free Trade Agreement
}

\begin{abstract}
The European Union and Japan have recently launched negotiations about a bilateral free trade agreement as means of economic stimulation, with trade as a driving force to create growth and wealth. Since customs duties are already low, the success of the liberalization process hinges on the potential elimination of non-tariff barriers. The purpose of this paper is to shed light on two possible liberalization scenarios, a less ambitious and a comprehensive trade liberalization. In contrast to classical studies our paper builds on the modern trade literature, accounting for the dominance of intra-industry trade between the two economies and the existence of heterogeneous firms. Furthermore, we model a search-and-matching labor market allowing us to quantify employment effects of trade liberalization. We find that a comprehensive liberalization increases Japanese GDP by 0.86 per cent, whereas the EU only experiences an additional 0.21 per cent of real GDP growth. Most of the growth in real GDP is due to firms' efficiency gains, while unemployment is only reduced by a small amount. Other world regions experience small reductions of GDP due to trade diversion effects.
\end{abstract}

JEL-Code: F120, F130, F160, F170.

Keywords: free trade agreement, intra-industry trade, gains from trade.

Sebastian Benz

Ifo Institute - Leibniz-Institute

for Economic Research

at the University of Munich

Poschingerstraße 5

Germany - 81679 Munich

benz@ifo.de
Erdal Yalcin*

Ifo Institute - Leibniz-Institute

for Economic Research

at the University of Munich

Poschingerstraße 5

Germany - 81679 Munich

yalcin@ifo.de

*corresponding author 


\section{Introduction}

Economic recovery since the financial crisis in 2008 has only been modest. Especially the world's largest economies, the EU, USA, and Japan, struggle with historically low growth rates and eroding competitiveness, shown for example by declining shares of these regions' exports in world trade (WTO-Report, 2013). They all are constrained by high and rising public debt loads leaving no more room for large scale national stimulus programmes. Japan appears to be in an even more futile economic situation characterized by a vicious circle of deflation - as consumers delay purchases, national enterprises see demand declining and investments are postponed.

In this difficult economic situation, the Japanese government has taken two bold measures to break out of economic stagnation. In 2013, as a first policy pillar the Bank of Japan backed by the newly elected government took dramatic actions and pledged convincingly to loosen monetary policy as a means of ending deflation on national markets, leading to a sharp depreciation of the Yen (30 per cent with respect to the US dollar within six months) and improving the international competitiveness of Japanese exporters, at least in the short run. The second important pillar in Japan's strategy for economic recovery is an increased activity in negotiating new regional trade agreements (RTAs), in particular with large trading blocks. Since trade liberalization within the World Trade Organization (WTO) came to a halt (the last negotiation round in Doha officially failed), regional trade liberalization gained importance. The number of regional trade agreements across the globe has skyrocketed to 546 notifications of which 354 are officially in force (cf. WTO, 2013). Herein, Japan has recently announced three large initiatives: a TransPacific-Partnership with the USA, the Japan-China-Korea FTA and finally, on 25 March 2013, Japan officially launched formal negotiations for a bilateral free trade agreement with the EU. ${ }^{1}$ In how far Japan's new free trade agreement initiatives, in particular with the listed large trading blocks will turn out to be an efficient means for economic recovery remains to be analyzed. ${ }^{2}$

The purpose of this article is a quantification of economic effects which can be expected from a successfully completed free trade agreement (FTA) between Japan and the European Union. To do so we build on an international trade model developed by Felbermayr et al. (2011, 2012). This framework offers the possibility to quantify labor market effects by combining a search-andmatching model à la Mortensen and Pissarides (1994) with a monopolistic competition setting and heterogeneous firms à la Melitz (2003). In addition to FTA effects on GDP, exports and terms of trades, our approach allows to quantify effects on the rate of unemployment. Likewise, it is possible to quantify firms' export participation rates and to analyze how average firm productivity emerges.

An explicit modelling of the labor market is especially relevant for the EU-Japan case, due

\footnotetext{
${ }^{1}$ In early 2013, the European Union (EU) and the USA have likewise agreed to initiate necessary procedures to launch negotiations on a Transatlantic Trade and Investment Partnership (TTIP).

${ }^{2}$ A complete list of Japan's and EU's free trade agreements is presented in the Appendix in Table A.1 and Table A.2.
} 
to the large asymmetry in the rate of unemployment. While the EU struggles with high unemployment for a relatively long time, the unemployment rate in Japan has remained relatively low, despite of the economic problems. Moreover, most trade between developed countries takes place in the manufacturing sectors and there exists a broad consensus that this exchange of goods is predominantly characterized by intra-industry trade. ${ }^{3}$ Descriptive statistics indeed confirm that trade between Japan and the EU has a strong intra-industry nature across all sectors (Grubel-Lloyd indices above 0.5). Therefore, a sound analysis of trade liberalization effects should primarily focus on the reallocation effects within industries à la Melitz (2003), as opposed to interindustry trade.

Consequently, our analysis is superior to previous studies that rely on a computable general equilibrium (CGE) model such as the Global Trade Analysis Project (GTAP), which is broadly used in this type of trade policy analysis. This class of models has several shortcomings: In general, they assume $(i)$ perfect competition among firms within the same industry. Furthermore, (ii) unemployment is often not accounted for, and (iii) parameterization of the models is not based on consistent econometric estimations - the extent of non-tariff barriers e.g. is often derived from surveys which rely on subjective perceptions. ${ }^{4}$

Besides Japan and the EU, we account for three further regions (NAFTA, ASEAN + China, and Rest of the World), which allows us to capture trade diversion effects. Observed real GDP values, unemployment rates, and bilateral export shares of all five regions are replicated in the baseline scenario. Subsequently, two different trade liberalization scenarios are simulated. First, we consider a less ambitious trade policy scenario in which only existing most-favored nation (MFN) tariffs are eliminated. Our second scenario simulates a comprehensive trade liberalization which includes a significant elimination of non-tariff barriers (NTB) - e.g., technical and sanitary regulations - between the EU and Japan in addition to the elimination of MFN tariffs.

However, the measurement of NTBs is not trivial. A commonly used identification strategy relies on the gravity equation (Anderson and van Wincoop, 2003). By controlling for all possible trade costs including tariff barriers the residual border effect which is quantified by boarder dummies can be interpreted as the average tariff equivalent NTB (cf. Winchester, 2009). The precision of this econometric approach is improved by controlling for multilateral resistance terms as discussed in Anderson and van Wincoop (2003). Other authors simply assume arbitrary advalorem equivalent NTB measures and apply them in numerical simulations. While the latter approach is unsatisfactory due to its arbitrariness the former identification strategy leads to biased measures due to the endogeneity of free trade agreements. ${ }^{5}$

\footnotetext{
${ }^{3}$ Agricultural exports from Japan to the EU represent less than 1 per cent of total exports. For the EU this number amounts to roughly 10 per cent in 2012.

${ }^{4}$ An alternative source for a criticism of GTAP based models can be found in Ackermann (2006).

${ }^{5}$ Egger et al. (2011) quantify free trade agreement effects by treating FTA as an endogenous determinant of bilateral trade. Furthermore, they provide an econometric approach respecting both bilateral and multilateral effects of endogenous FTA on international trade.
} 
To address these well documented challenges we suggest a new approach how NTBs should be accounted for. ${ }^{6}$ In a recent empirical study Felbermayr et al. (2013) estimate average trade creation effects of FTAs in 126 countries accounting for all related regional trade agreements registered at the WTO until 2005, following Egger et al. (2011) and Egger and Larch (2011) to account for potential endogeneity. The average trade creation effect they find is a 74 per cent increase in bilateral trade. Hence, in our comprehensive liberalization scenario we adjust bilateral trade cost parameters between Japan and the EU up to a point at which aggregate bilateral trade rises by 74 per cent. The resulting reduction in NTBs including tariff duties amounts to 18.6 per cent (measured as ad-valorem equivalent). ${ }^{7}$ With these settings we discuss trade creation and diversion effects of the two different liberalization scenarios, as well as their implications for welfare.

Our simulation results predict that a mere elimination of tariffs will increase real GDP in Japan by 0.07 per cent, whereas the EU experiences only a rise of around 0.02 per cent. These effects turn out to be much higher in a comprehensive trade liberalization scenario. Japan is predicted to experience a real GDP growth of 0.86 per cent and the EU of 0.21 per cent. China and the ASEAN region have to expect a small GDP drop by 0.05 per cent in a comprehensive liberalization scenario due to trade diversion effects, whereas China and ASEAN, NAFTA, and the Rest of the World experience no perceivable real GDP effects in the tariff scenario. Unemployment effects turn out to be negligible after an elimination of tariffs, while an ambitious NTB elimination leads to a drop in Japanese unemployment by 0.02 per cent, and European employment rises by 0.01 per cent. Similarly, real wages are hardly affected with a mere tariff elimination policy. However, in the comprehensive liberalization scenario Japanese employees can expect on average real wage gains of around 0.9 per cent whereas European wages rise by 0.2 per cent. The predicted increases in real wages are due to a higher average productivity of labor. This is driven by the fact that trade liberalization leads to a reallocation of employment away from companies with low labor productivity towards companies with high labor productivity. Furthermore, in both scenarios Japan and the EU experience a drop in the number of domestic firms, accompanied by a rise in average firm sizes.

The remainder of this paper is organized as follows. The next section depicts relevant descriptive statistics. Section 3 briefly describes the theoretical model and section 4 continues with its calibration. In section 5 we discuss the simulation results before we conclude in section 6 .

\footnotetext{
${ }^{6}$ Until now, there exits no well-established methodology by means of which one could estimate NTBs consistently across countries and sectors in a harmonized way, so that the results could be safely used in model simulations.

${ }^{7}$ Related studies derive ad-valorem equivalent NTBs for Japan and the EU from surveys stating that exports costs increase by 10 to 30 per cent due to NTB (EU-COM, 2012; Francois et al., 2009).
} 


\section{Stylized Facts}

For the last decade the EU and Japan have been the largest and third largest economies in the world, respectively. Together they account for around 45 per cent of world GDP and 25 per cent of world trade. The bilateral trade relationship between the two regions is extremely important for both economies. In 2011, Japan was ranked sixed among the major European export destinations (with 3.6 per cent of EU's total exports going to Japan). The European Union turns out to be the third most important export destination for Japanese companies, with 12.4 per cent of Japan's total exports going to the EU.

Table I: Grubel-Lloyd index for EU-Japan relationship Japan as the reporting authority

\begin{tabular}{lccc}
\hline Industry & $\begin{array}{c}\text { Japanese } \\
\text { Exports } \\
\text { to the EU }\end{array}$ & $\begin{array}{c}\text { Japanese } \\
\text { Imports } \\
\text { from the EU }\end{array}$ & GL-Index \\
\hline Total Manufacturing & \multicolumn{2}{c}{ in billion USD } & \\
\hline Electrical and Optical Equipment & 100.73 & 63.64 & 0.77 \\
Motor Vehicles, Trailers and Semi-Trailers & 31.20 & 9.76 & 0.48 \\
Machinery \& Equipment, n.e.c. & 25.22 & 9.00 & 0.53 \\
Chemicals \& Chemical Products & 18.98 & 6.96 & 0.54 \\
Other Transport Equipment & 8.65 & 15.22 & 0.72 \\
Rubber \& Plastics Products & 4.95 & 1.37 & 0.43 \\
Basic Metals & 2.88 & 0.87 & 0.47 \\
Fabricated Metal Products & 2.38 & 2.56 & 0.96 \\
Coke, Refined Petroleum Prod. \& Nuclear Fuel & 0.71 & 0.97 & 0.85 \\
& & 0.72 & 0.99
\end{tabular}

\begin{tabular}{lccc} 
Aggregates - OECD Grouping & & & \\
\hline Medium-High Technology Industries & 22.01 & 48.17 & 0.63 \\
Low Technology Industries & 21.07 & 8.90 & 0.59 \\
Medium-Low Technology Industries & 14.00 & 19.40 & 0.84 \\
High Technology Industries & 2.49 & 9.49 & 0.42 \\
\hline
\end{tabular}

Notes: Listed industries are classified according to ISIC rev. 3 and sorted by their export/import volumes from/to Japan to/from the EU in the year 2007. Export and import values are expressed in billion US dollars, and are reported by the Japanese customs authorities. The last column lists the Grubel Lloyd index for leading Japanese export industries and is calculated according to the following formula: $G L_{i}=\frac{\left(X_{i}+M_{i}\right)-\left|X_{i}-M_{i}\right|}{X_{i}+M_{i}} \equiv 1-\frac{\left|X_{i}-M_{i}\right|}{X_{i}+M_{i}}$ with $0 \leq G L_{i} \leq 1$, where $X=$ exports and $M=$ imports, $i=$ industry. For $G L$ close to 0 the respective Japanese industry merely exports or imports goods to/from the EU. For $G L$ above 0.5 imports and exports in the respective industries are equivalent $($ for $G L=1$ perfectly balanced.) We calculate $G L$ index values for the year 2007 in order to consider a pre-crises situation. OECD industry groups are explained in the appendix in Table C.1.

Source: OECD Statistics, STAN Bilateral Trade Database. 
Table I lists bilateral exports and imports of Japanese industries to and from the EU sorted by export volumes to the EU. The last column contains the Grubel Lloyd (GL) index (Grubel and Lloyd, 1971) for each industry. GL index values above 0.5 indicate a high degree of intraindustry trade. ${ }^{8}$ Six out of the listed nine industries exhibit Grubel Lloyd index values above 0.5. Total trade in the manufacturing industry is highly balanced resulting in an index value of 0.77 . Accordingly, across most of the leading export industries, trade between Japan and the EU has a strong intra-industry nature. These high GL values point to the two economies' similarity in terms of wage cost and productivity.

With intra-industry trade being dominant in the Japanese-EU trade relationship, it is not very likely that a comprehensive trade liberalization will result in sectoral specialization in one or the other economy. Instead, any elimination of bilateral trade barriers should boost trade through adjustments within industries, characterized by growth of highly productive exporting firms on the one side and the elimination of less competitive smaller firms on the other side.

Table II provides Japan's and the EU's MFN tariff distributions including average MFN duties. It turns out that 42 per cent of Japan's bound product lines are not subject to import duties. In the EU 27 per cent of all product lines are unprotected. Overall, in both economies around 85 per cent of all duties are below 10 per cent, while Japan shows a stronger skewness towards zero bounds. Except for a handful of traded goods with tariff peaks the remaining product lines reach import duties of 27.9 per cent in the EU and 36.9 per cent in Japan. Peak tariff rates reach 61.9 per cent in Japan and 74.9 per cent in the EU. In 2011, trade weighted average bound MFN tariff rates amounted to approximately 2 per cent. Due to the mentioned tariff peaks, unweighted average tariff rates turn out to be slightly higher. ${ }^{9}$

These figures show that for a sizeable number of goods, tariffs still play a role and their elimination is relevant for welfare. Nonetheless, in comparison to other countries, the average tariff rates between the EU and Japan are at very low levels (China e.g. has a simple average MFN bound rate of 10 per cent). It is therefore unlikely that the elimination of these relatively low tariffs will lead to strong trade and welfare effects in the aggregate.

The repeated reductions in tariffs resulting from the General Agreement on Tariffs and Trade (GATT) and from succeeding WTO negotiating rounds replaced mean tariffs on goods by NTBs as the major sources of import protection (cf. WTO-Report, 2012). Nowadays, governments are more and more concerned with elimination or alleviation of non-tariff trade barriers. In general, any non-price and non-quantity restriction on trade is considered a non-tariff barrier. Particularly, standards and technical regulations represent the most important type of NTBs (WTO-report, 2013). They increase the complexity and uncertainty of cross border business resulting in additional cost. These type of barriers vary in their contractual design across countries

\footnotetext{
${ }^{8}$ Table I presents OECD data reported by Japanese authorities. Table B.1 in the appendix provides the same table based on OECD data provided by EU authorities. While there are differences in the GL values the dominance of intra-industry trade between Japan and the EU is confirmed.

${ }^{9}$ Japan exhibits a simple average MFN tariff rate of 3.08 per cent while the EU reaches 4.27 per cent.
} 
Table II: MFN Bound Tariff Distributions for Japan and the EU, 2011

Japanese MFN Bound Tariffs Rates, 2011

\begin{tabular}{rrrrr}
\hline Duty range & No. of lines & \% Lines & Cum. no. of lines & Cum. \% lines \\
\hline All Items (Excl. N.A.) & 8.359 & 100 & 8.359 & 100 \\
Duty Free & 3.545 & 42 & 3.545 & 42 \\
$0-3.9 \%$ & 1.536 & 18 & 5.081 & 61 \\
$4-6.9 \%$ & 1.299 & 16 & 6.38 & 76 \\
$7-9.9 \%$ & 815 & 10 & 7.195 & 86 \\
$10-12.9 \%$ & 480 & 6 & 7.675 & 92 \\
$13-15.9 \%$ & 84 & 1 & 7.759 & 93 \\
$16-18.9 \%$ & 95 & 1 & 7.854 & 94 \\
$19-21.9 \%$ & 151 & 2 & 8.005 & 96 \\
$22-24.9 \%$ & 70 & 1 & 8.075 & 97 \\
$25-27.9 \%$ & 130 & 2 & 8.205 & 98 \\
$28-30.9 \%$ & 95 & 1 & 8.3 & 99 \\
$31-33.9 \%$ & 0 & - & 8.3 & 99 \\
$34-36.9 \%$ & 30 & 0 & 8.33 & 99.9 \\
\hline Simple average MFN bound tariff: & & $\mathbf{3 . 0 8 \%}$ \\
Trade weighted average MFN bound tariff: &
\end{tabular}

European MFN Bound Tariffs Rates, 2011

\begin{tabular}{rrrrr}
\hline Duty range & No. of lines & \% of lines & Cum. no. of lines & Cum. \% of lines \\
\hline All Items (Excl. N.A.) & 8.319 & 100 & 8.319 & 100 \\
Duty Free & 2.252 & 27 & 2.252 & 27 \\
$0-3.9 \%$ & 2.197 & 26 & 4.449 & 53 \\
$4-6.9 \%$ & 1.92 & 23 & 6.369 & 77 \\
$7-9.9 \%$ & 856 & 10 & 7.225 & 87 \\
$10-12.9 \%$ & 613 & 7 & 7.838 & 94 \\
$13-15.9 \%$ & 183 & 2 & 8.021 & 96 \\
$16-18.9 \%$ & 137 & 2 & 8.158 & 98 \\
$19-21.9 \%$ & 53 & 1 & 8.211 & 99 \\
$22-24.9 \%$ & 62 & 1 & 8.273 & 99 \\
$25-27.9 \%$ & 30 & 0 & 8.303 & 99.9 \\
\hline Simple average MFN bound tariff: & & $\mathbf{4 . 2 7 \%}$ \\
Trade weighted average MFN bound tariff: & & $\mathbf{2 . 4 5 \%}$ \\
\hline
\end{tabular}

Notes: The table lists bound MFN tariff rates for all products (including sub-headings classified in HS2007) in Japan and the EU, respectively. The resulting tariff distributions illustrates that for 42 per cent of bound lines Japan exhibits zero duties, while the EU has kept 27 per cent of its bound product lines as duty free. In both regions around 85 per cent of all duties are below 10 per cent. Average bound MFN tariffs amount to 4 per cent with trade weighted averages MFN bound tariffs reaching 2 per cent. A small number of products exhibit over average tariff peaks. Peak rates reach 61.9 per cent in Japan and 74.9 per cent in the EU.

Source: WTO's Integrated Data Base (IDB) and Consolidated Tariff Schedules (CTS). 
or products, and hence, are in contrast to customs duties difficult to be quantified.

In related work, Kee et al. (2008) develop trade barrier measures referred to as overall trade restrictiveness indices (OTRI), which allow the quantification of international trade barriers including tariffs. The authors convincingly illustrate that NTBs have a significant contribution to the level of trade restrictiveness measured by OTRI. On average NTBs are responsible for an additional 87 percent to the level of trade restrictiveness imposed by tariffs.

Accordingly, in industrial economies NTBs represent the major source of remaining trade

restrictions. Furthermore, internationally conducted surveys reveal that on average NTBs lead to 15 to 30 percentage points additional trade costs if quantified as ad-valorem equivalent (cf. Felbermayr et al. 2013). Hence, the elimination of NTBs comprises a considerable degree of welfare gains, substantially higher than by a mere tariff elimination. However, there is no wellestablished methodology by means of which one could estimate NTBs consistently across countries and sectors in a harmonized way, so that the results could be safely used in model simulations.

\section{The Model}

Given the potential of reallocation effects within industries after a trade liberalization between Japan and the EU, an appropriate policy analysis should be built on a monopolistic competition framework. Therefore, our model focuses primarily on the reallocation effects within industries, and builds on Felbermayr, Prat, and Schmerer (2011) and Felbermayr, Larch, and Lechthaler (2012) who made important contributions by combining the Mortensen-Pissarides (1994) searchand-matching labor market framework with the Melitz (2003) model of trade with heterogenous firms.

Labor is the only factor of production and is used to produce intermediate products under monopolistic competition by firms with different levels of productivity $\phi$. Domestic and foreign intermediates are than used to manufacture a final consumption good without any further input of labor under perfect competition. The production function in country $i$, where $i=1, \ldots, N$, can be written as

$$
Q_{i}=\left(\bar{M}_{i}^{\frac{\nu-i}{\sigma}} \int_{\phi \in \Omega_{i}} q(\phi)^{\frac{\sigma-1}{\sigma}} d \phi\right)^{\frac{\sigma}{\sigma-1}}
$$

where $\bar{M}_{i}$ is the set of intermediates available in country $i, \nu$ determines the extent of scale economies, $\sigma$ is the elasticity of substitution between varieties, and $q(\phi)$ denotes quantity of intermediates manufactured by firms with productivity $\phi$. The final product $Q_{i}$ is always consumed in the country where it is produced.

Operating revenues of a firm with productivity $\phi$ based in country $i$ from sales to market $j$ are given by $R_{i j}(\phi)=p_{i j}(\phi) q_{i j}(\phi) / \tau_{i j}$, where $p_{i j}(\phi)$ is the price that this firm charges in $j$ and 
$\tau_{i j}>1$ are iceberg transport costs (with $\tau_{i i}=1$ ). The inverse demand function is given by

$$
p_{i j}(\phi)=\left(\frac{q_{i j}(\phi)}{t_{i j}}\right)^{-\frac{1}{\sigma}} P_{j}^{\frac{\sigma-1}{\sigma}}\left(\frac{Y_{j}}{\bar{M}_{j}^{1-\nu}}\right)^{\frac{1}{\sigma}},
$$

with a price index $P_{j}=\left(\bar{M}_{j}^{\nu-1} \int_{\phi \in \Omega_{j}} p_{i j}^{1-\sigma} d \phi\right)^{1 /(1-\sigma)}$ so that a firm's accumulated revenue over all markets can be written as

$$
R_{i}(\phi)=\sum_{j=1}^{N} I_{i j}(\phi) q_{i j}(\phi)^{\frac{\sigma-1}{\sigma}} P_{j}^{\frac{\sigma-1}{\sigma}}\left(\frac{\tau_{i j}^{1-\sigma} Y_{j}}{\bar{M}_{j}^{1-\nu}}\right)^{\frac{1}{\sigma}}
$$

where the indicator function $I_{i j}(\phi)$ takes the value one if a firm with productivity $\phi$ from country $i$ is active in market $j$ and zero otherwise.

Output of an intermediate goods producer in $i$ delivered to $j$ is given by $q_{i j}(\phi)=\phi A_{i} L_{i j}(\phi)$, where $A_{i}$ is country-specific labor productivity and $L_{i j}(\phi)$ is employment in the firm used for production of goods for delivery to $j$. These intermediate goods producers are potentially hit by two independent shocks at the end of each period. With probability $\delta$ a firm has to leave the market and with probability $\chi$ a firm-worker relationship breaks up. The rate of job destruction is thus given by $\eta=1-(1-\delta)(1-\chi)$. The share of vacancies filled each period is given by $\bar{m}_{i} \theta_{i}^{-\alpha_{i}}$, where $\bar{m}_{i}$ is the efficiency of the labor market, $\theta_{i}$ is the vacancy-unemployment ratio, and $\alpha_{i}$ is the elasticity of the matching function. The value function maximized by each intermediate input producer is given by

$$
\begin{aligned}
J_{i}(\phi)= & \max _{v_{i}(\phi)} \frac{1}{1+r}\left(R_{i}(\phi)-w_{i}(\phi) L_{i}(\phi)-P_{i} v_{i}(\phi) c_{i}-P_{i} \sum_{j=1}^{N} I_{i j}(\phi) f_{i j}+(1-\delta) J_{i}^{\prime}(\phi)\right) \\
& \text { s.t. } \quad L_{i}^{\prime}(\phi)=(1-\chi) L_{i}(\phi)+\bar{m}_{i} \theta_{i}^{-\alpha_{i}} v_{i}(\phi),
\end{aligned}
$$

where $r$ is the interest rate, $w_{i}(\phi)$ is the wage rate, $v_{i}(\phi)$ is the number of vacancies, and the indicates levels in the next period. The flow value of a firm is made up of revenues minus the wage costs for workers, the costs of job posting, and fixed costs for each market where it is active. The maximization constraint indicates that the stock of workers in the next period is the sum of workers remaining employed in a firm plus newly hired workers. The first order condition which solves this problem is given by

$$
\frac{\partial J_{i}^{\prime}(\phi)}{\partial L_{i}^{\prime}(\phi)}=\frac{1}{1-\delta} \frac{c_{i} P_{i}}{\bar{m}_{i} \theta_{i}^{-\alpha_{i}}},
$$

so that differentiation of Equation (4) with respect to $L_{i j}$ yields the shadow value of labor

$$
\frac{\partial J_{i}(\phi)}{\partial L_{i}(\phi)}=\frac{\partial J_{i}(\phi)}{\partial L_{i j}(\phi)}=\frac{1}{r+\eta}\left(\frac{\partial R_{i}(\phi)}{\partial L_{i j}(\phi)}-w_{i}(\phi)-\frac{\partial w_{i}(\phi)}{\partial L_{i j}(\phi)} L_{i j}(\phi)\right) .
$$

The difference between the value of being employed at a firm with productivity $\phi$ in country 
$i$ and the value of being unemployed results from

$$
E_{i}(\phi)-U_{i}=\frac{w_{i}(\phi)-r U_{i}}{r+\eta}
$$

We assume that wages are bargained at the beginning of each period before production takes place. Moreover, every worker is treated as being the marginal worker with a bargaining power $\beta_{i} \in(0,1)$, which implies that

$$
\left(1-\beta_{i}\right)\left(E_{i}(\phi)-U_{i}\right)=\beta_{i} \frac{\partial J_{i}(\phi)}{\partial L_{i j}(\phi)}
$$

Plugging Equations (6) and (7) into Equation (8) we obtain a solution for the wage rate

$$
w_{i}(\phi)=\beta_{i}\left(\frac{\sigma}{\sigma-\beta}\right) \frac{\partial R_{i}(\phi)}{\partial L_{i j}(\phi)}+\left(1-\beta_{i}\right) r U_{i}
$$

The value of unemployment is given by $U_{i}=\left(b_{i} \Phi_{i} P_{i}+\theta_{i} \bar{m}_{i} \theta_{i}^{-\alpha_{i}} \bar{E}_{i}+\left(1-\theta \bar{m}_{i} \theta_{i}^{-\alpha_{i}}\right) U_{i}\right) /(1+r)$, where $\bar{E}_{i}$ is the value of employment at the average firm and $\Phi_{i}:=\tilde{\phi}_{i i} p_{i i}\left(\tilde{\phi}_{i i}\right) / P_{i}$ with $\tilde{\phi}_{i i}$ being the productivity of the average firm. Using the fact that $\frac{\partial R_{i}(\phi)}{\partial L_{i j}}=\left(\frac{\sigma-1}{\sigma}\right) \phi A_{i} p_{i i}$ we can solve for the job creation curve

$$
\frac{w_{i}}{P_{i}}=\frac{\sigma-1}{\sigma-\beta_{i}} \Phi_{i}-\frac{c_{i}}{\bar{m}_{i} \theta_{i}^{-\alpha_{i}}} \frac{r+\eta}{1-\delta}
$$

which is downward sloping in $\theta$. The intuition is that the cost of filling vacancies rises with the tightness on the labor market, so that the real wage of workers has to fall.

Moreover, combining Equations (5) and (6) with the expression for the wage rate in Equation (9) we can solve for $w_{i}=r U_{i}+\beta(r+\eta) c_{i} P_{i} /\left(1-\beta_{i}\right)(1-\delta)\left(\bar{m}_{i} \theta_{i}^{-\alpha_{i}}\right)$ and using $r U_{i}=b_{i} \Phi_{i} P_{i}+$ $\theta_{i} \bar{m}_{i} \theta_{i}^{-\alpha_{i}}\left(\bar{E}_{i}-U_{i}\right)$ we can derive the wage curve as

$$
\frac{w_{i}}{P_{i}}=b_{i} \Phi_{i}+\frac{\beta_{i}}{1-\beta_{i}} \frac{c_{i}}{1-\delta}\left(\frac{r+\eta}{\bar{m}_{i} \theta_{i}^{-\alpha_{i}}}+\theta_{i}\right),
$$

which is increasing in $\theta$ since the cost of wage negotiations breaking down is higher for firms when the labor market is tight. The equilibrium on the labor market is characterized by the intersection of the job creation curve and the wage curve.

As it is standard in all Melitz-type models, there exists an infinite number of potential entrants into the market. After paying a fixed entry cost $f^{e}$ they draw their productivity from a distribution function $g(\phi)$ with cumulative probability being given by $G(\phi)$. A firm will be active in all markets where revenue exceeds the variable and fixed costs of production. This is true for all firms with $\phi \geq \phi_{i j}^{*}$, where $\phi_{i j}^{*}$ is the productivity of the marginal entrant from $i$ into market $j$ determined by

$$
\frac{1-\delta}{r+\delta} \pi_{i j}\left(\phi_{i j}^{*}\right)=\frac{P_{i} c_{i}}{\bar{m}_{i} \theta_{i}^{-\alpha_{i}}} L_{i j}\left(\phi_{i j}^{*}\right)+P_{i} f_{i j}
$$


and the profit flow in each period is given by $\pi_{i j}(\phi)=R_{i j}(\phi)-\left(w_{i}+\frac{P_{i} c_{i} \chi}{\bar{m}_{i} \theta_{i}^{-\alpha_{i}}}\right) L_{i j}(\phi)-P_{i} f_{i j}$. We focus on situations where $\phi_{i i}^{*}<\phi_{i j}^{*}$. Hence, entry from $i$ into a market $j$ is successful with an ex ante probability of $1-G\left(\phi_{i j}^{*}\right)$ such that we can define the average productivity of those firms as $\tilde{\phi}_{i j}=\left(\left(1-G\left(\phi_{i j}^{*}\right)\right)^{-1} \int_{\phi_{i j}^{*}}^{\infty} \phi_{i}^{\sigma-1} g\left(\phi_{i}\right) d \phi_{i}\right)$ and the free entry condition is given by

$$
f^{e} P_{i}=\sum_{j=1}^{N}\left(1-G\left(\phi_{i j}^{*}\right)\right)\left(\frac{1-\delta}{r+\delta} \pi_{i j}\left(\tilde{\phi}_{i j}\right)-\frac{P_{i} c_{i}}{\bar{m}_{i} \theta_{i}^{-\alpha_{i}}} L_{i j}\left(\tilde{\phi}_{i j}\right)-P_{i} f_{i j}\right) .
$$

The labor market clearing condition determines the relationship between labor supply in country $i$ and aggregate employment as $L_{i}^{e}=L_{i}\left(1-u_{i}\right)$. A constant rate of unemployment implies that flows in and out of employment must be equal $\eta\left(1-u_{i}\right)=\bar{m}_{i} \theta_{i}^{-\alpha_{i}} v_{i}$. The mass of firms in each country $i$ is determined by the size of the workforce $M_{i}=L_{i}^{e} /\left(\sum_{j=1}^{N} \psi_{i j} L_{i j}\left(\tilde{\phi}_{i j}\right)\right)$, where $\psi_{i j}=\left(1-G\left(\phi_{i j}^{*}\right)\right) /\left(1-G\left(\phi_{i i}^{*}\right)\right)$ is defined as the probability of exporting to $j$ conditional on entering the domestic market $i$. Moreover, the mass of firms remains constant over time so that leading to $\delta M_{i}=(1-\delta)\left(1-G\left(\phi_{i i}^{*}\right)\right) M_{i}^{e}$, where $M_{i}^{e}$ denotes the mass of firms that pays the fixed entry costs $f^{e}$.

Intermediate inputs are traded and trade balance is maintained. This enables us to determine aggregate income as the sum of wage payments, flow fixed costs, upfront investment costs and hiring costs

$$
\sum_{j=1}^{N} M_{i} \psi_{i j} R_{i j}(\tilde{\phi})=w_{i} L_{i}^{e}+\frac{P_{i} M_{i}}{1-\delta}\left((1+r) \sum_{j} \psi_{i j} f_{i j}+\frac{r+\delta}{1-G\left(\phi_{i j}^{*}\right)} f^{e}\right)+\frac{\eta+r}{1-\delta} \frac{P_{i} c_{i} L_{i}^{e}}{\bar{m}_{i} \theta_{i}^{-\alpha_{i}}} .
$$

\section{Calibration}

We calibrate the model with discrete time and choose one unit of time in our model to represent one month. Assuming an annual discount rate of 4 per cent this implies a monthly discount rate $r=0.33$ per cent. The monthly hazard rate of exiting the market is set to 0.91 per cent, as suggested by Bartelsmann, Haltiwanger, and Scarpetta (2004). We follow Blanchard and Giavazzi (2003) in setting the parameter of external scale economies $\nu=0$ so that unemployment does not depend on country size. The elasticity of substitution $\sigma$ is set to five, following Anderson and van Wincoop (2003). Following Ghironi and Melitz we assume that firms draw their productivity from a Pareto distribution with minimum productivity of one. The shape parameter is given by $\gamma=5.5$, which implies that 8 per cent of NAFTA firms are active in an export market outside of the NAFTA region. This is in line with evidence from Bernard et al. (2007a) who report that the export participation rate of US manufacturing firms is 18 per cent, but more than half of these firms only export to one single market.

Bernard et al. (2007b) argue that the choice of fixed entry costs only rescales the size of the 
Table III: Baseline calibration of parameter values

\begin{tabular}{llll} 
Symbol & Description & Value & Source \\
\hline$r$ & Discount rate & $0.33 \%$ & $4 \%$ annual discount rate \\
$\delta$ & Rate of firm exit & $0.91 \%$ & Bartelsmann et al. (2004) \\
$\nu$ & External scale economies & 0 & Blanchard and Giavazzi (2003) \\
$\sigma$ & Elasticity of substitution & 5 & Anderson and van Wincoop (2003) \\
$\bar{\phi}$ & Minimum value of productivity & 1 & Ghironi and Melitz (2004) \\
$\gamma$ & Shape of Pareto Distribution & 5.5 & Bernard et al. (2007a) \\
$f^{e}$ & Fixed entry cost & 0.1 & Arbitrary \\
$f$ & Fixed cost of production & 0.005 & Bernard et al. (2007b) \\
$f^{x}$ & Fixed foreign market access cost & 0.0085 & Felbermayr et al. (2011) \\
$\alpha$ & Elasticity of matching function & 0.5 & Petrongolo and Pissarides (2001) \\
$\beta$ & Bargaining power & 0.5 & Abowd and Allain $(1996)$ \\
$\xi_{i}$ & Rate of match-specific separation & $2.5 \%$ & Job separation rate $=3.4 \% ;$ Shimer $(2005)$ \\
$c$ & Cost of posting a vacancy & 1.954 & To match $\theta=0.5 ;$ Hall $(2005)$ \\
$b_{i}$ & Unemployment benefits & 0.4 & Bassanini and Duval $(2006)$ \\
\hline
\end{tabular}

average firms. We follow their approach by setting $f^{e}$ to 0.1 and using a ratio of fixed entry cost to fixed cost of production of 0.05 , so that $f=0.005$. In analogy to Felbermayr, Prat, and Schmerer (2011) we assume that fixed cost of exporting are higher than fixed cost of production by a factor 1.7 , which yields $f^{x}=0.0085$.

We assume an elasticity of the matching function of 0.5 as found by Petrongolo and Pissarides (2001). Bargaining power is equal for workers and firms, as suggested by Abowd and Allain (1996). Match specific shocks arrive with a rate of 2.5 per cent, which yields 3.4 per cent for the monthly rate of job separation as found by Shimer (2005). The cost of vacancy posting is calibrated to 1.954, such that the tightness of the labor market $\theta=0.5$ as suggested by Hall (2005). Finally, following Bassanini and Duval we set the shift parameter of unemployment benefits to 0.4, which yields a ratio of unemployment benefits to wages of roughly 0.45 .

In our model the world is made up of five regions: Japan, the European Union $(\mathrm{EU})^{10}$, China + ASEAN $(\mathrm{Ch}+\mathrm{A})^{11}, \mathrm{NAFTA}^{12}$, and the rest of the world (RoW). The population size of these regions is taken from World Bank data and we assume an employment ratio of 0.5 for all regions.

Our baseline calibration is based on data from the year 2007 to avoid potential confounding effects from the financial crisis starting in 2008 and targets two key statistics of each region: GDP per capita and unemployment rates. Using data from the World Bank, we calculate the unemployment rate in a region as the population-weighted average of country-level unemployment

\footnotetext{
${ }^{10}$ Members of the EU are Austria, Belgium, Bulgaria, Cyprus, Czech Republic, Denmark, Estonia, Finland, France, Germany, Greece, Hungary, Ireland, Italy, Latvia, Lithuania, Luxembourg, Malta, Netherlands, Poland, Portugal, Romania, Slovakia, Slovenia, Spain, Sweden, and the United Kingdom.

${ }^{11}$ ASEAN is the Association of Southeast Asian Nations. Its members are Brunei, Cambodia, Indonesia, Laos, Malaysia, Myanmar, Philippines, Singapore, Thailand, and Vietnam.

${ }^{12}$ NAFTA is the North American Free Trade Agreement, signed by the United States, Canada, and Mexico.
} 
Table IV: Calibrated country statistics

\begin{tabular}{l|lllll} 
& Japan & $\mathrm{EU}$ & $\mathrm{Ch}+\mathrm{A}$ & NAFTA & RoW \\
\hline Unemployment rate & $3.90 \%$ & $7.13 \%$ & $4.36 \%$ & $4.41 \%$ & $4.49 \%$ \\
GDP per capita & $34,094.89$ & $34,187.80$ & $2,647.29$ & $37,037.79$ & $3,529.97$ \\
Labor productivity $A_{i}$ & $4,928.162$ & $5,503.245$ & 366.655 & $6,257.814$ & 511.449 \\
Matching efficiency $\bar{m}_{i}$ & 1.15502 & 0.64157 & 1.00085 & 1.03832 & 1.0
\end{tabular}

Notes: This table shows the unemployment rate and GDP per capita of the five regions which we target in our calibration, together with the resulting parameters for labor productivity and matching efficiency. Due to the lack of data on unemployment in the Rest of the World, we simply assume a matching efficiency of 1.0. Unemployment rate is in per cent. GDP per capita is in US-dollars.

rates and GDP per capita as the population-weighted average of country-level GDP per capita. ${ }^{13}$ We can exactly reproduce these statistics by adjusting labor productivity and the efficiency parameter of matching on the labor market in the five regions. The targeted statistics and resulting parameter values are reported in Table IV.

Moreover, we calibrate bilateral trade costs between the regions to match observed exports flows as a share of the exporter's GDP. ${ }^{14}$ China and ASEAN is the most open of the five regions, followed by the EU and the RoW. However, note that a substantial amount of trade takes place within these regions, which are all made up of a high number of countries. For example, only 11 per cent of the EU's GDP is made up of exports out of the EU, which is lower than the Japanese export share of 16 per cent. The bilateral ad-valorem trade barriers that we obtain by our simulation are reasonable, given that they present the only distortion of trade flows in our model. For example, Japan faces an ad-valorem trade barrier of 69.8 per cent for exports into the EU, while EU exporters face an ad-valorem trade barrier of 118.3 per cent for exports to Japan. The fact that no other distortion of trade is present in our model means that zero trade barriers in our model predict an export share of $1-G D P_{i} / G D P_{W o r l d}$, which is clearly far from what the data tell us. The reason is that these flows are not only shaped by trade costs, but to a large amount are determined by country-specific preferences, which we do not account for in our model. Bilateral ad-valorem trade barriers for all country-pairs are reported in Appendix D. Our calibrated model yields exporter productivity premia that are within a range of what is commonly reported. For example, Japanese exporters to the EU are 87 per cent more productive than the average Japanese firm.

\footnotetext{
${ }^{13}$ We do not have unemployment data for the Rest of the World, but assume a matching efficiency of 1.0.

${ }^{14}$ We do not match trade flows within a region. These are reported in Table V only for the sake of completeness. Ad-valorem trade barriers within a region are set to zero.
} 
Table V: Bilateral and total export/GDP

\begin{tabular}{|c|c|c|c|c|c|c|c|}
\hline & \multicolumn{5}{|c|}{ Importer } & \multirow[b]{2}{*}{ Sum } \\
\hline & & Japan & $\mathrm{EU}$ & $\mathrm{Ch}+\mathrm{A}$ & NAFTA & RoW & \\
\hline \multirow{5}{*}{ 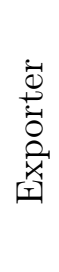 } & Japan & $0.00 \%$ & $2.42 \%$ & $5.40 \%$ & $3.82 \%$ & $4.67 \%$ & $16.31 \%$ \\
\hline & $\mathrm{EU}$ & $0.36 \%$ & $21.50 \%$ & $1.23 \%$ & $2.56 \%$ & $6.53 \%$ & $32.19 \%$ \\
\hline & $\mathrm{Ch}+\mathrm{A}$ & $4.11 \%$ & $7.95 \%$ & $16.38 \%$ & $8.68 \%$ & $11.40 \%$ & $48.52 \%$ \\
\hline & NAFTA & $0.43 \%$ & $1.73 \%$ & $0.96 \%$ & $5.60 \%$ & $2.20 \%$ & $10.92 \%$ \\
\hline & RoW & $1.73 \%$ & $8.04 \%$ & $4.58 \%$ & $3.97 \%$ & $9.03 \%$ & $27.34 \%$ \\
\hline
\end{tabular}

Notes: This table shows the ratio of bilateral trade flows between regions over the exporting region's GDP. Each exporter is characterized by a row and each importer is characterized by a column. The column "Sum" displays aggregate exports relative to GDP. Exports within a region can only be positive if the region is composed of several countries, it does not contain flows of goods within a country.

\section{Simulation Results}

Based on the delineated general equilibrium model we examine two possible trade policy scenarios. ${ }^{15}$ The first simulation assumes a complete elimination of all import duties and represents the less ambitious liberalization scenario. It can be considered as the minimum achievable free trade agreement between Japan and the EU. With reference to the average tariff rates illustrated in Table II, variable trade costs are reduced by 1.9 per cent and 2.45 per cent in Japan and the EU, respectively.

Given the importance of NTBs in determining trade flows, our second policy simulation has a particular focus on how a substantial NTB elimination between Japan and the EU may effect both economies. We call this second simulation comprehensive trade liberalization, since it implies that the negotiating parties can resolve detailed and complex trade barriers arising from countryspecific standards and technical regulations. We estimate the level of NTBs based on recent empirical contributions which quantify the average trade creation effect of regional and free trade agreements. Egger et al. (2011), Felbermayr et al. (2013) estimate average trade creation effects of FTAs in 126 countries accounting for all related regional trade agreements registered at the WTO until 2005. According to this ex-post FTA evaluation trade barrier elimination increases bilateral trade flows on average by 74 per cent.

Therefore, in our comprehensive trade liberalization scenario we assume that trade creation between Japan and the EU is equivalent to the estimates of Felbermayr et al. (2013). ${ }^{16}$ This means that the initially calibrated bilateral trade barriers in our baseline model are reduced such

\footnotetext{
${ }^{15}$ Simulation codes are available upon request.

${ }^{16}$ Felbermayr et al. (2013) take into account the non-random occurrence of free trade agreements, which is crucial in estimating consistent effects of FTAs. This is achieved through the use of an instrumental variables estimator. Furthermore, the authors carefully model that the start-up of trade relationships between two countries may be subject to other economic laws than the intensification of pre-existing economic relationships.
} 
Table VI: Aggregate exports in billion US dollars

\begin{tabular}{lrrrrr}
\hline Aggregate exports & Japan & EU & Ch+A & NAFTA & ROW \\
\hline Baseline Scenario & 709.95 & $1,794.66$ & $1,601.32$ & 900.24 & $2,388.56$ \\
\hline Tariff Scenario & 716.71 & $1,801.38$ & $1,600.89$ & 900.06 & $2,388.24$ \\
Absolute Change & 6.76 & 6.72 & -0.43 & -0.19 & -0.19 \\
Relative Change & $0.95 \%$ & $0.37 \%$ & $-0.03 \%$ & $-0.02 \%$ & $-0.01 \%$ \\
\hline NTB Scenario & 786.48 & $1,869.54$ & $1,596.86$ & 898.24 & $2,384.41$ \\
Absolute Change & 76.53 & 74.88 & -4.46 & -2.01 & -4.15 \\
Relative Change & $10.78 \%$ & $4.17 \%$ & $-0.28 \%$ & $-0.22 \%$ & $-0.17 \%$ \\
\hline
\end{tabular}

Notes: This table shows aggregate exports of each of the five regions going out of the respective region. Exports to other countries of the same region are not included. Values are reported for our baseline scenario, as well as the two simulated scenarios. "Tariff scenario" indicates the case where bilateral tariffs between the EU and Japan are eliminated. "NTB Scenario indicates the case where bilateral trade barriers between the EU and Japan are reduced by 18.6 percentage points, leading to an increase of bilateral trade flows of 74. per cent. All values are in billion US dollars.

that bilateral trade creation predicted by the model is exactly 74 per cent. The reduction includes the elimination of all tariffs and partial elimination of NTBs. For simplicity we assume that the absolute reduction of bilateral trade barriers is identical for trade flows in both directions. This can also be justified by the fact that the elimination of NTBs is subject to negotiations. Thus, it is plausible that cutbacks are relatively equal, even if the ex ante level of NTBs differs. This reversed identification strategy indicates an elimination of NTBs equivalent to a 18.6 per cent reduction of bilateral ad-valorem trade barrier. As mentioned above, this estimate of the quantitative importance of NTB barriers is in line with estimates from other studies, e.g. Francois et al. (2009). Trade creation from the symmetric reduction of trade barriers is slightly asymmetric, due to differences in the level of trade barriers. Our simulation suggests that exports from the EU to Japan increase slightly more than exports from Japan to the EU. For more details see Table XI below.

One of the key predictions of our model concerns the aggregate trade volume. Table VI reports aggregate exports of the five regions in the baseline scenario and in the two FTA scenarios in billion US dollars. To facilitate comparison of results we calculate absolute and relative changes with respect to the baseline scenario. One can easily see that both, Japan and the EU, significantly increase their export volume. Both countries experience additional exports of around 6.7 billion US dollars in the tariff scenario and additional exports of around 75 billion US dollars in the NTB scenario. However, since the export volume of the EU in the baseline case is substantially larger than the export volume of Japan, this relatively similar increase in absolute terms represents different relative changes. While Japanese exports increase by roughly 1 per cent in the tariff scenario and 11 per cent in the NTB scenario, exports of the EU only increase by 0.4 per cent in the tariff scenario and 4.2 per cent in the NTB scenario. 
Table VII: Real GDP in billion US dollars

\begin{tabular}{lrrrrr}
\hline Real GDP & Japan & EU & Ch + A & NAFTA & ROW \\
\hline Baseline Scenario & $4,356.33$ & $16,990.03$ & $5,006.16$ & $16,421.80$ & $13,056.52$ \\
\hline Tariff Scenario & $4,359.57$ & $16,993.26$ & $5,005.92$ & $16,421.63$ & $13,056.34$ \\
Absolute Change & 3.24 & 3.23 & -0.23 & -0.16 & -0.18 \\
Relative Change & $0.07 \%$ & $0.02 \%$ & $0.00 \%$ & $0.00 \%$ & $0.00 \%$ \\
\hline NTB Scenario & $4,393.64$ & $17,025.63$ & $5,003.74$ & $16,420.10$ & $13,054.10$ \\
Absolute Change & 37.32 & 35.60 & -2.41 & -1.69 & -2.42 \\
Relative Change & $0.86 \%$ & $0.21 \%$ & $-0.05 \%$ & $-0.01 \%$ & $-0.02 \%$ \\
\hline
\end{tabular}

Notes: This table shows the Gross Domestic Product of each of the five regions. Values are reported for our baseline scenario, as well as the two simulated scenarios. GDP in the two simulated scenarios are calculated by multiplying resulting growth rate of real GDP by the initial GDP. "Tariff scenario" indicates the case where bilateral tariffs between the EU and Japan are eliminated. "NTB Scenario" indicates the case where bilateral trade barriers between the EU and Japan are reduced by 18.6 percentage points, leading to an increase of bilateral trade flows of 74 . per cent. All values are in billion US dollars.

Exports of the other three regions are negatively affected by an FTA between Japan and the EU. However, the drop in exports is relatively small. Exports of China and the ASEAN region decline by 0.03 per cent in the tariff scenario and 0.28 per cent or 4.5 billion US dollars in the NTB scenario. Exports from NAFTA drop by 0.02 per cent in the tariff scenario and 0.22 per cent in the NTB scenario, which corresponds to 2 billion US dollars. Exports of the Rest of the World only fall by 0.01 per cent in the tariff scenario and 0.17 in the NTB scenario. This implies a reduction of exports of roughly 4 billion US dollars.

Changes of the aggregate export volume are matched by qualitatively identical changes of the five regions' real GDP, reported in Table VII. However, real GDP growth rates induced by a Japan-EU FTA are substantially smaller than export growth. While Japan experiences a growth of real GDP by 0.07 per cent in the tariff scenario and 0.86 per cent in the NTB scenario, effects in Europe are even smaller. Real GDP of the EU only grows by 0.02 per cent when abolishing tariffs between Japan and the EU and by 0.21 per cent when signing a comprehensive FTA. This difference is due to the asymmetry in the size of the two countries. Since the EU is a much larger market than Japan, trade liberalization with the EU has stronger effects on Japan than any trade liberalization with Japan can have on the EU. Effects on real GDP in the other three regions are always negative but extremely small: China and ASEAN contract by 0.05 per cent, NAFTA by 0.01 per cent and the Rest of the World by 0.02 per cent.

Changes in real GDP are mirrored by changes in umemployment. However, as shown in Table VIII and IX, our model predicts these changes to be relatively small. Comparing the NTB scenario with the baseline scenario we find that the Japanese unemployment rate falls by 0.016 percentage points, corresponding to roughly 10,000 jobs, whereas the elimination of tariffs only creates 880 jobs in Japan. Effects on unemployment in the EU are somewhat smaller in 
Table VIII: Unemployment rate (in \%)

\begin{tabular}{lrrrrr}
\hline Unemployment rate (in \%) & Japan & EU & Ch+A & NAFTA & ROW \\
\hline Baseline Scenario & 3.9000 & 7.1300 & 4.3600 & 4.4100 & 4.4858 \\
\hline Tariff Scenario & 3.8986 & 7.1293 & 4.3601 & 4.4101 & 4.4858 \\
Absolute Change & -0.0014 & -0.0007 & 0.0001 & 0.0001 & 0.0000 \\
\hline NTB Scenario & 3.8837 & 7.1228 & 4.3611 & 4.4103 & 4.4862 \\
Absolute Change & -0.0163 & -0.0072 & 0.0011 & 0.0003 & 0.0004 \\
\hline
\end{tabular}

Notes: This table shows the unemployment rate of each of the five regions. Values are reported for our baseline scenario, as well as the two simulated scenarios. "Tariff scenario" indicates the case where bilateral tariffs between the EU and Japan are eliminated. "NTB Scenario indicates the case where bilateral trade barriers between the EU and Japan are reduced by 18.6 percentage points, leading to an increase of bilateral trade flows of 74. per cent. All values are in per cent.

terms of the unemployment rate $(-0.007$ percentage points in the NTB scenario) but larger in absolute terms, creating an additional 18,000 jobs in the NTB scenario and 1,700 jobs in the tariff scenario. Effects on unemployment in the remaining regions are mostly negative: China and ASEAN lose 1,352 jobs in the tariff scenario and around 10,000 jobs in the NTB scenario; the NAFTA area loses roughly 100 jobs in the tariff scenario and 560 in the NTB scenario; the Rest of the World can reduce unemployment by 240 jobs in the tariff scenario but moving to the NTB scenario increases the number of unemployed by 6,700 .

Table IX: Unemployment (persons)

\begin{tabular}{lrrrrr}
\hline Unemployment (persons) & Japan & EU & Ch + A & NAFTA & ROW \\
\hline Baseline Scenario & $2,491,530$ & $17,716,688$ & $41,224,922$ & $9,776,517$ & $82,959,638$ \\
\hline Tariff Scenario & $2,490,649$ & $17,715,009$ & $41,226,274$ & $9,776,631$ & $82,959,398$ \\
Absolute Change & -880 & $-1,680$ & 1,352 & 113 & -240 \\
\hline NTB Scenario & $2,481,144$ & $17,698,770$ & $41,235,058$ & $9,777,078$ & $82,966,370$ \\
Absolute Change & $-10,385$ & $-17,918$ & 10,136 & 561 & 6,732 \\
\hline
\end{tabular}

Notes: This table shows the number of unemployed of each of the five regions. Values are reported for our baseline scenario, as well as the two simulated scenarios. "Tariff scenario" indicates the case where bilateral tariffs between the EU and Japan are eliminated. "NTB Scenario indicates the case where bilateral trade barriers between the EU and Japan are reduced by 18.6 percentage points, leading to an increase of bilateral trade flows of 76 per cent. All values indicate the number of unemployed people.

Table X reports effects on the average firm productivity. As we know from Melitz (2003), trade liberalization increases the competition on the domestic market of the liberalizing countries. This means that selection becomes tougher, the entry cutoff rises and the least efficient firms can no longer survive. This selection effect is extremely important for the benefits of an FTA between Japan and the EU. Average firm productivity in the NTB scenario increases by 0.56 per cent 
Table X: Average firm productivity

\begin{tabular}{lrrrrr}
\hline Average firm productivity & Japan & EU & Ch+A & NAFTA & ROW \\
\hline Baseline Scenario & 2.2396 & 2.1978 & 2.3406 & 2.1844 & 2.2525 \\
\hline Tariff Scenario & 2.2407 & 2.1981 & 2.3405 & 2.1843 & 2.2525 \\
Relative Change & $0.0495 \%$ & $0.0117 \%$ & $-0.0027 \%$ & $-0.0005 \%$ & $-0.0008 \%$ \\
\hline NTB Scenario & 2.2523 & 2.2007 & 2.3399 & 2.1842 & 2.2523 \\
Relative Change & $0.5642 \%$ & $0.1305 \%$ & $-0.0280 \%$ & $-0.0054 \%$ & $-0.0099 \%$ \\
\hline
\end{tabular}

Notes: This table shows the average productivity of active firms in each of the five regions. Values are reported for our baseline scenario, as well as the two simulated scenarios. "Tariff scenario" indicates the case where bilateral tariffs between the EU and Japan are eliminated. "NTB Scenario indicates the case where bilateral trade barriers between the EU and Japan are reduced by 18.6 percentage points, leading to an increase of bilateral trade flows of 74. per cent. All values indicate the average productivity drawn from the Pareto distribution of all firms staying active in the market.

in Japan and 0.13 per cent in the EU which is roughly two thirds of the overall effect on real GDP. This puts the relatively small effects on unemployment reported above into a different light. Indeed, most welfare gains from an FTA between Japan and the EU do not come from creation of new jobs, but from the fact that existing jobs are now in firms with higher average productivity.

In the following we have a closer look at the pattern of trade diversion effect. Table XI shows Japanese exports to the EU, EU exports to Japan, and for the remaining three regions the sum of exports going to Japan and the EU. The first two columns show that trade flows between Japan and the EU increase substantially. In the tariff scenario Japan exports 5.6 billion US dollars more to the EU than in the baseline scenario. This implies a relative increase of 5.3 per cent. In the NTB Scenario the increase in bilateral exports from Japan to the EU is even 70.4 billion US dollars, or 67 per cent. EU exports to Japan rise by 4.7 billion US dollars in the tariff scenario and 49 billion US dollars in the NTB scenario, corresponding to a relative increase of 7.7 per cent and 80 per cent, respectively. The relative increase in the sum of bilateral trade between Japan and the EU is 74 per cent, as described at the beginning of this section.

The last three columns of Table XI show that the negative impact on aggregate exports of the other three regions mostly stems from a negative impact on their exports to Japan and the EU, although the effect is small. While China and the ASEAN region experience a reduction of exports to Japan and the EU of around 1.2 per cent in the NTB scenario, exports from NAFTA and the Rest of the World to Japan and the EU only fall by 0.6 per cent and 0.2 per cent, respectively. This means that aggregate imports of Japan and the EU increase substantially.

Taking a complementary point of view, Table XII reports the sum of exports to the other three regions of our calibrated model: China and the ASEAN countries, NAFTA, and the Rest of the World. In analogy to above, the last three columns only report the sum of exports to the respective other two regions. This table shows that Japan and the EU are qualitatively differently affected by a bilateral FTA. While Japan does not only experience increasing exports 
Table XI: Exports to EU + Japan in billion US dollars

\begin{tabular}{lrrrrr}
\hline Exports to EU + Japan & Japan & EU & Ch+A & NAFTA & ROW \\
\hline Baseline Scenario & 105.42 & 60.99 & 601.59 & 375.57 & 1276.28 \\
\hline Tariff Scenario & 110.98 & 65.69 & 600.80 & 375.37 & 1276.15 \\
Absolute Change & 5.58 & 4.70 & -0.79 & -0.20 & -0.20 \\
Relative Change & $5.27 \%$ & $7.70 \%$ & $-0.13 \%$ & $-0.05 \%$ & $-0.01 \%$ \\
\hline NTB Scenario & 175.79 & 109.93 & 594.17 & 373.43 & 1273.61 \\
Absolute Change & 70.37 & 48.94 & -7.42 & -2.14 & -2.67 \\
Relative Change & $66.75 \%$ & $80.24 \%$ & $-1.23 \%$ & $-0.57 \%$ & $-0.21 \%$ \\
\hline
\end{tabular}

Notes: This table shows aggregate exports of each of the five regions going to either the EU or Japan. The column "EU" only reports exports to Japan, the column "Japan" only reports exports to the EU. Values are reported for our baseline scenario, as well as the two simulated scenarios. "Tariff scenario" indicates the case where bilateral tariffs between the EU and Japan are eliminated. "NTB Scenario indicates the case where bilateral trade barriers between the EU and Japan are reduced by 18.6 percentage points, leading to an increase of bilateral trade flows of 74. per cent. All values are in billion US dollars.

Table XII: Exports to $\mathrm{Ch}+\mathrm{A} / \mathrm{NAFTA} / \mathrm{ROW}$ in billion US dollars

\begin{tabular}{lrrrrr}
\hline Exports to Ch+A/NAFTA/ROW & Japan & EU & Ch+A & NAFTA & ROW \\
\hline Baseline Scenario & 604.53 & $1,733.66$ & 999.73 & 524.68 & $1,112.29$ \\
\hline Tariff Scenario & 606.03 & $1,731.53$ & $1,000.09$ & 524.69 & $1,112.08$ \\
Absolute Change & 1.50 & -2.13 & 0.36 & 0.01 & -0.20 \\
Relative Change & $0.25 \%$ & $-0.12 \%$ & $0.04 \%$ & $0.00 \%$ & $-0.02 \%$ \\
\hline NTB Scenario & 614.52 & $1,716.53$ & $1,002.68$ & 524.84 & $1,110.90$ \\
Absolute Change & 9.99 & -17.14 & 2.95 & 0.16 & -1.38 \\
Relative Change & $1.65 \%$ & $-0.99 \%$ & $0.30 \%$ & $0.03 \%$ & $-0.12 \%$ \\
\hline
\end{tabular}

Notes: This table shows aggregate exports of each of the five regions going to all countries but the EU and Japan. In the column "Ch+A" exports between China and the ASEAN countries are excluded. In the column "NAFTA" exports within NAFTA are excluded. The column "RoW" only reports the sum of exports to China, the ASEAN countries, and NAFTA. Values are reported for our baseline scenario, as well as the two simulated scenarios. "Tariff scenario" indicates the case where bilateral tariffs between the EU and Japan are eliminated. "NTB Scenario indicates the case where bilateral trade barriers between the EU and Japan are reduced by 18.6 percentage points, leading to an increase of bilateral trade flows of 74 . per cent. All values are in billion US dollars.

to the EU, but also to the other regions of our model, the effect of an FTA with Japan on EU's exports to the remaining regions is negative. This effect is not due to differences in the trade pattern of Japan and the EU. In fact, Japan experiences export growth with all three regions, China + ASEAN, NAFTA, and the Rest of the World, while EU exports to all these regions decline. The explanation can be found in a stronger selection effect in Japan, implying that the least productive firms have to exit the market and the market share of more productive firms 
increases. As was shown in Table $\mathrm{X}$ above, productivity in Japan increase five times more than in the EU. Logically, a higher productivity increases the competitiveness of Japanese firms in all markets.

Moreover, our simulation shows that the reduction in the mass of firms is strongest in Japan. The number declines by 2.2 per cent in the NTB scenario, because firms that start exporting to an additional market need to hire a substantial amount of workers. The selection effect in Europe is much smaller, showing a reduction in the mass of firms of 0.5 per cent in the NTB scenario. As discussed above, this differences is due to the asymmetry in the size of the two economies. The mass of firms in the other three regions increases slightly in the NTB scenario. In China and ASEAN by 0.1 per cent, in NAFTA by 0.2 per cent and in the Rest of the World by 0.2 per cent.

\section{Conclusion}

Japan and the European Union have taken important steps toward deepening their trade relationship by starting formal negotiations on a free trade agreement. Both region's governments intend to boost economic growth by creating one of the world's largest bilateral trade accords in terms of trade volume. The attempt to vitalize Japanese and European markets through higher international competition stands out of increasing protectionist steps discussed as possible policy alternatives (cf. EU's tariffs on Chinese solar panels). Compared to other free trade agreements, that have been completed in recent years, or are currently being negotiated, the Japan-EU FTA initiative features several particularities. On the one hand, the negotiating partners are very similar in their economic development levels, exhibit strong mutual investment positions, and maintain deep political ties. The exchange of goods between Japan and the EU is dominated by intra-industry trade, and hence any elimination of trade barriers will certainly not result in strong sectoral specialization. On the other hand cultural proximity is relative low compared to respective neighboring countries.

Tariffs as classical trade barriers play a minor role for both economies, with average MFN bound tariffs being below 5 per cent. Consequently, to achieve a substantial stimulation of the economy, trade liberalization has to go beyond a mere customs duty elimination. Both economies provide enough opportunities to reduce non-tariff barriers across different sectors not only because of the prevailing cultural differences but also due to historically established country specific standards and technical regulations. However, the willingness to do so will depend on each side's expectations related to any NTB reduction. Hence, it is crucial to provide decisions-makers with potential and realistic outcomes of different policy scenarios.

This paper is the first attempt to quantify economic effects of a free trade agreement between Japan and the EU accounting for the two economies' mentioned particularities, namely the importance of intra-industry trade and an appropriate consideration of NTBs. In contrast to related policy studies the presented simulation builds on a monopolistic competition model extended by a search-matching framework of the labor market. We belief, that simulations with classical CGE 
models are not able to plausibly capture the structure of the two economies.

Our simulations predict that a less ambitious trade liberalization, confined to a mere customs duties elimination, will result in a 0.07 per cent increase of Japanese GDP while Europe only experiences additional growth of 0.02 per cent. Growth effects are substantial in a comprehensive liberalization case with Japanese GDP increasing by 0.86 per cent. However, even with an ambitious trade barrier elimination expected GDP growth in Europe remains on a low level at 0.2 per cent. Employment creation that can be expected from such an agreement are relatively low. However, our model predicts a high firm entry and exit dynamics in both economies in which less productive firms are forced out of the market and more productive firms grow. Aggregating these effects, Japan and the EU experience a significant increase in productivity in the ambitious scenario ranging around 0.5 per cent for Japan and 0.1 per cent in the EU.

Across all considered economic measures our simulations predict a slightly higher gain for Japan compared to the EU, due to the relatively larger size of the European economy relative to Japan. However, it would be naive to conclude that the EU should be less eager to pursuit an ambitious elimination of trade barriers due to the expected asymmetric welfare effects. Trade negotiations between Japan and the EU have to be seen in a broader context, as several regional free trade negotiations are initiated in East-Asia and the Asia-Pacific region, including the US-led Trans-Pacific Partnership (TPP) to which Japan is expected to join in due course. If the EU fails to be involved in these ongoing movements, it will lag behind in the process of economic integration in the Asian region leaving future liberalization attempts look more difficult.

One point of criticism arising in the context of a comprehensive agreement between Japan and the EU is that such a trade deal will put other countries at a disadvantage. Moreover, it is often concluded that this would jeopardize the functioning of the World Trade Organization (WTO) and hinder the successful conclusion of a multilateral agreement (post Doha Round). Indeed, in the short run our simulation predict negative effects for the other regions in our model. However, the high number of new regional and free trade agreements among leading trading countries also allows an opposite conclusion. Ever more countries see the necessity to participate in liberalization process, even so they are on regional levels. Recent empirical research points at the possibility that the conclusion of important bilateral agreements actually increases the incentives of third parties to achieve further liberalization steps at the multilateral level (cf. Baldwin \& Seghezza, 2010). 


\section{Literature}

Ackerman, F. (2006). "Assessing the Effects of Trade Liberalization: A Critical Examination," Rivista dell'Associazone Rossi-Doria.

Abowd, J. M. and Laurence Allain (1996). "Compensation Structure and Product Market Competition," Annales d'Economie et de Statistique, 41/42, 207-218.

Anderson, J. E. And Eric van Wincoop (2003). "Gravity with Gravitas: A Solution to the Border Puzzle," American Economic Review, 93(1), 170-192

Baldwin, R. And Elena Seghezza (2010). "Are Trade Blocs Building or Stumbling Blocs?," Journal of Economic Integration, 25(2), 276-297.

Bartelsmann, E., J. Haltiwanger, and S. Scarpetta (2004). "Microeconomic Evidence of Creative Destruction in Industrial and Developing Countries," IZA Discussion Paper, No. 1374.

Bassanini, A. And Romain Duval (2006). "Employment Patterns in OECD Countries: Reassessing the Role of Policies and Institutions," Organisation for Economic Co-Operation and Development (OECD) Economics Department Working Paper, No. 486.

Bernard, A., Bradford Jensen, Stephen Redding and Peter Schott (2007a). "Firms in International Trade," Journal of Economic Perspectives, 21(3), 105-130.

Bernard, A., Stephen Redding and Peter Schott (2007b). "Comparative Advantage and Heterogeneous Firms," Review of Economic Studies, 74(1), 31-66.

Blanchard, O. and Francesco Giavazzi (2003). "Macroeconomic Effects of Regulation and Deregulation in Goods and Factor Markets," Quarterly Journal of Economics, 118, 879-907.

EU-COM (2012). "Impact Assessment Report on EU-Japan Trade Relations," European Commission Staff Working Document, Brussels.

Egger, P. and Mario Larch (2011). "An Assessment of the Europe Agreements' Effects on Bilateral Trade, GDP, and Welfare," European Economic Review, 55(2), 263-279

Egger, P., Mario Larch, Kevin E. Staub, and Rainer Winkelmann (2011). "The Trade Effects of Endogenous Preferential Trade Agreements," American Economic Journal: Economic Policy, 3(3), 113-43.

Felbermayr, G. J., Sebastian Benz, Lisandra Flach, Mario larch, and Erdal YALCIN (2013). "Dimensions and Impact of a Free Trade Agreement Between the EU and the USA," Evaluation Study for the German Ministry of Economics and Technology. www.ifo.de/w/3kC6QR3vF. 
Felbermayr, G. J., Mario Larch, and Wolfgang Lechthaler (2012). "The ShimerPuzzle of International Trade: A Quantitative Analysis," Ifo Working Paper Series Ifo Working Paper, No. 134.

Felbermayr, G. J., Mario Larch, and Wolfgang Lechthaler (2013). "Unemployment in an Interdependent World," American Economic Journal: Economic Policy, 5(1), 262-301.

Felbermayr, G. J., Julien Prat, and Hans-Jörg Schmerer (2011). "Globalization and labor market outcomes: Wage bargaining, search frictions, and firm heterogeneity," Journal of Economic Theory, 146(1), 39-73.

Francois, J. F., Eva R. Sunesen, and Martin H. Thelle (2009). "Assessment of Barriers to Trade and Investment between the EU and Japan," Final Report for the European Commission, DG Trade.

Ghironi, F. And Marc J. Melitz (2005). "International Trade and Macroeconomic Dynamics with Heterogeneous Firms," Quarterly Journal of Economics, 120(3), 865-915.

Grubel, H.G. And P.J. Lloyd (1971). "The Empirical Measurement of Intra-Industry Trade," Economic Record, 47, 494-517.

Hall, R. (2005). "Employment Fluctuations with Equilibrium Wage Stickiness," American Economic Review, 95(1), 50-65.

Kee, H. L., Alessandro Nicita, and Marcelo Olarreaga (2009). "Estimating Trade Restrictiveness Indices," Economic Journal, 119, 172-199.

Melitz, M. (2003). "The Impact of Trade on Intra-Industry Reallocations and Aggregate Industry Productivity," Econometrica, 71(6), 1695-1725.

Mortensen, D. T. And Christopher A. Pissarides (1994). "Job Creation and Job Destruction in the Theory of Unemployment," Review of Economic Studies, 61(3), 397-415.

Petrongolo, B. and Christopher A. Pissarides (2001). "Looking into the Black Box: A Survey of the Matching Function," Journal of Economic Literature, 39, 390-431.

Shimer, R. (2005). "The Cyclical Behavior of Equilibrium Unemployment and Vacancies," American Economic Review, 91(1), 25-49.

Winchester N. (2009). "Is there a Dirty Little Secret? Non-Tariff Barriers and the Gains from Trade," Journal of Policy Modeling, 31, 819-834.

WTO-Report (2012). "Annual Report 2012. World Trade Organization," World Trade Organization, Geneva.

WTO-Report (2013). "Annual Report 2013. World Trade Organization." World Trade Organization, Geneva. 


\section{Appendix}

\section{A EU's and Japan's Existing Trade Agreements}

Table A.1: Japan's Free Trade and Economic Integration Agreements

\begin{tabular}{|l|r|r|r|r|}
\hline Free Trade Agreement & Coverage & Type & Year & Status \\
\hline Japan - ASEAN & Goods & FTA & 2008 & In Force \\
\hline Japan - Brunei Darussalam & Goods / Services & FTA / EIA & 2008 & In Force \\
\hline Japan - Chile & Goods / Services & FTA / EIA & 2007 & In Force \\
\hline Japan - India & Goods / Services & FTA / EIA & 2011 & In Force \\
\hline Japan - Indonesia & Goods / Services & FTA / EIA & 2008 & In Force \\
\hline Japan - Malaysia & Goods / Services & FTA / EIA & 2006 & In Force \\
\hline Japan - Mexico & Goods / Services & FTA / EIA & 2005 & In Force \\
\hline Japan - Peru & Goods / Services & FTA / EIA & 2012 & In Force \\
\hline Japan - Philippines & Goods / Services & FTA / EIA & 2008 & In Force \\
\hline Japan - Singapore & Goods / Services & FTA / EIA & 2002 & In Force \\
\hline Japan - Switzerland & Goods / Services & FTA / EIA & 2009 & In Force \\
\hline Japan - Thailand & Goods / Services & FTA / EIA & 2007 & In Force \\
\hline Japan - Viet Nam & Goods / Services & FTA / EIA & 2009 & In Force \\
\hline
\end{tabular}

Notes: This table lists Japan's free trade agreements (FTA) and economic integration agreements (EIA), as defined in Article V of GATS.

Source: WTO - Regional Trade Agreements Information System 
Table A.2: EU's Free Trade and Economic Integration Agreements

\begin{tabular}{|c|c|c|c|c|}
\hline Free Trade Agreement & Coverage & Type & Year & Status \\
\hline Cent. European FTA (CEFTA) 2006 & Goods & FTA & 2007 & In Force \\
\hline EU - Albania & Goods / Services & FTA / EIA & $2006(\mathrm{G}) / 2009(\mathrm{~S})$ & In Force \\
\hline EU - Algeria & Goods & FTA & 2005 & In Force \\
\hline EU - Andorra & Goods & $\mathrm{CU}$ & 1991 & In Force \\
\hline EU - Bosnia and Herzegovina & Goods & FTA & 2008 & In Force \\
\hline EU - Cameroon & Goods & FTA & 2009 & In Force \\
\hline EU - CARIFORUM States EPA & Goods / Services & FTA / EIA & 2008 & In Force \\
\hline EU - Central America & Goods / Services & FTA / EIA & & In Force \\
\hline EU - Chile & Goods / Services & FTA / EIA & $2003(\mathrm{G}) / 2005(\mathrm{~S})$ & In Force \\
\hline EU - Colombia and Peru & Goods / Services & FTA / EIA & 2013 & In Force \\
\hline EU - Côte d'Ivoire & Goods & FTA & 2009 & In Force \\
\hline EU - Croatia & Goods / Services & FTA / EIA & $2002(\mathrm{G}) / 2005(\mathrm{~S})$ & In Force \\
\hline EU - Eastern \& Southern Africa States & Goods & FTA & 2012 & In Force \\
\hline EU - Egypt & Goods & FTA & 2004 & In Force \\
\hline EU - Faroe Islands & Goods & FTA & 1997 & In Force \\
\hline EU - Former Yugoslav. Rep. of Macedonia & Goods / Services & FTA / EIA & $2001(\mathrm{G}) / 2004(\mathrm{~S})$ & In Force \\
\hline EU - Iceland & Goods & FTA & 1973 & In Force \\
\hline EU - Israel & Goods & FTA & 2000 & In Force \\
\hline EU - Jordan & Goods & FTA & 2002 & In Force \\
\hline EU - Korea, Republic of & Goods / Services & FTA / EIA & 2011 & In Force \\
\hline EU - Lebanon & Goods & FTA & 2003 & In Force \\
\hline EU - Mexico & Goods / Services & FTA / EIA & $2000(\mathrm{G}) / 2000(\mathrm{~S})$ & In Force \\
\hline EU - Montenegro & Goods / Services & FTA / EIA & $2008(\mathrm{G}) / 2010(\mathrm{~S})$ & In Force \\
\hline EU - Morocco & Goods & FTA & 2000 & In Force \\
\hline EU - Norway & Goods & FTA & 1973 & In Force \\
\hline EU - Overseas Count. and Territ. & Goods & FTA & 1971 & In Force \\
\hline EU - Palestinian Authority & Goods & FTA & 1997 & In Force \\
\hline EU - Papua New Guinea / Fiji & Goods & FTA & 2009 & In Force \\
\hline EU - San Marino & Goods & $\mathrm{CU}$ & 2002 & In Force \\
\hline EU - Serbia & Goods & FTA & 2010 & In Force \\
\hline EU - South Africa & Goods & FTA & 2000 & In Force \\
\hline EU - Switzerland - Liechtenstein & Goods & FTA & 1973 & In Force \\
\hline EU - Syria & Goods & FTA & 1977 & In Force \\
\hline EU - Tunisia & Goods & FTA & 1998 & In Force \\
\hline EU - Turkey & Goods & $\mathrm{CU}$ & 1996 & In Force \\
\hline EU (28) Enlargement & Goods / Services & $\mathrm{CU} / \mathrm{EIA}$ & 2013 & In Force \\
\hline Eurasian Economic Community & Goods & $\mathrm{CU}$ & 1997 & In Force \\
\hline European Economic Area & Services & EIA & 1994 & In Force \\
\hline European Free Trade Association & Goods / Services & FTA / EIA & $1960(\mathrm{G}) / 2002(\mathrm{~S})$ & In Force \\
\hline
\end{tabular}

Notes: This table lists EU's free trade agreements (FTA) and economic integration agreements (EIA), as defined in Article V of GATS.

Source: WTO - Regional Trade Agreements Information System 


\section{B Grubel Lloyd Index for EU-Japan relationship}

Table B.1: Grubel-Lloyd index for EU-Japan relationship EU as the reporting authority

\begin{tabular}{lccc}
\hline Industry & $\begin{array}{c}\text { EU Exports } \\
\text { to Japan }\end{array}$ & $\begin{array}{c}\text { EU Imports } \\
\text { from Japan }\end{array}$ & GL-Index \\
\hline in billion USD & \\
Total Manufacturing & 57.00 & 122.83 & 0.63 \\
\hline Chemicals \& Chemical Products & 11.78 & 11.61 & 0.99 \\
Electrical \& Optical Equipment & 9.80 & 41.98 & 0.38 \\
Motor Vehicles, Trailers \& Semi-Trailers & 8.65 & 28.38 & 0.47 \\
Machinery \& Equipment, n.e.c. & 6.61 & 21.94 & 0.46 \\
Basic Metals & 2.00 & 2.14 & 0.97 \\
Other Transport Equipment & 1.63 & 6.06 & 0.42 \\
Fabricated Metal Products & 1.13 & 1.76 & 0.79 \\
Rubber \& Plastics Products & 0.90 & 3.35 & 0.42 \\
Coke, Refined Petroleum Prod. \& Nuclear Fuel & 0.68 & 0.71 & 0.98 \\
& & & \\
Aggregates - OECD Grouping & & & 0.52 \\
\hline Medium-High Technology Industries & 24.56 & 70.46 & 0.53 \\
High Technology Industries & 13.89 & 38.47 & 0.48 \\
Low-Technology Industries & 13.01 & 4.09 & 0.72 \\
Medium-Low Technology Industries & 5.48 & 9.76 & \\
\hline
\end{tabular}

Notes: Listed industries are classified according to ISIC rev. 3 and sorted by according to the their export/import volumes from/to EU to/from Japan in the year 2007. Export and import values are expressed in billion US dollars, and are reported by the EU customs authorities. The last column lists the Grubel Lloyd index for leading EU export industries and is calculated according to the following formula: $G L_{i}=\frac{\left(X_{i}+M_{i}\right)-\left|X_{i}-M_{i}\right|}{X_{i}+M_{i}} \equiv 1-\frac{\left|X_{i}-M_{i}\right|}{X_{i}+M_{i}}$ with $0 \leq G L_{i} \leq 1$, where $X=$ exports and $M=$ imports, $i=$ industry. For $G L$ close to 0 the respective EU industry merely exports or imports goods to/from Japan. For $G L$ above 0.5 imports and exports in the respective industries are equivalent (for $G L=1$ perfectly balanced.) We calculate $G L$ index values for the year 2007 in order to consider a pre-crises situation. OECD industry groups are explained in the Appendix in Table C.1.

Source: OECD Statistics, STAN Bilateral Trade Database. 


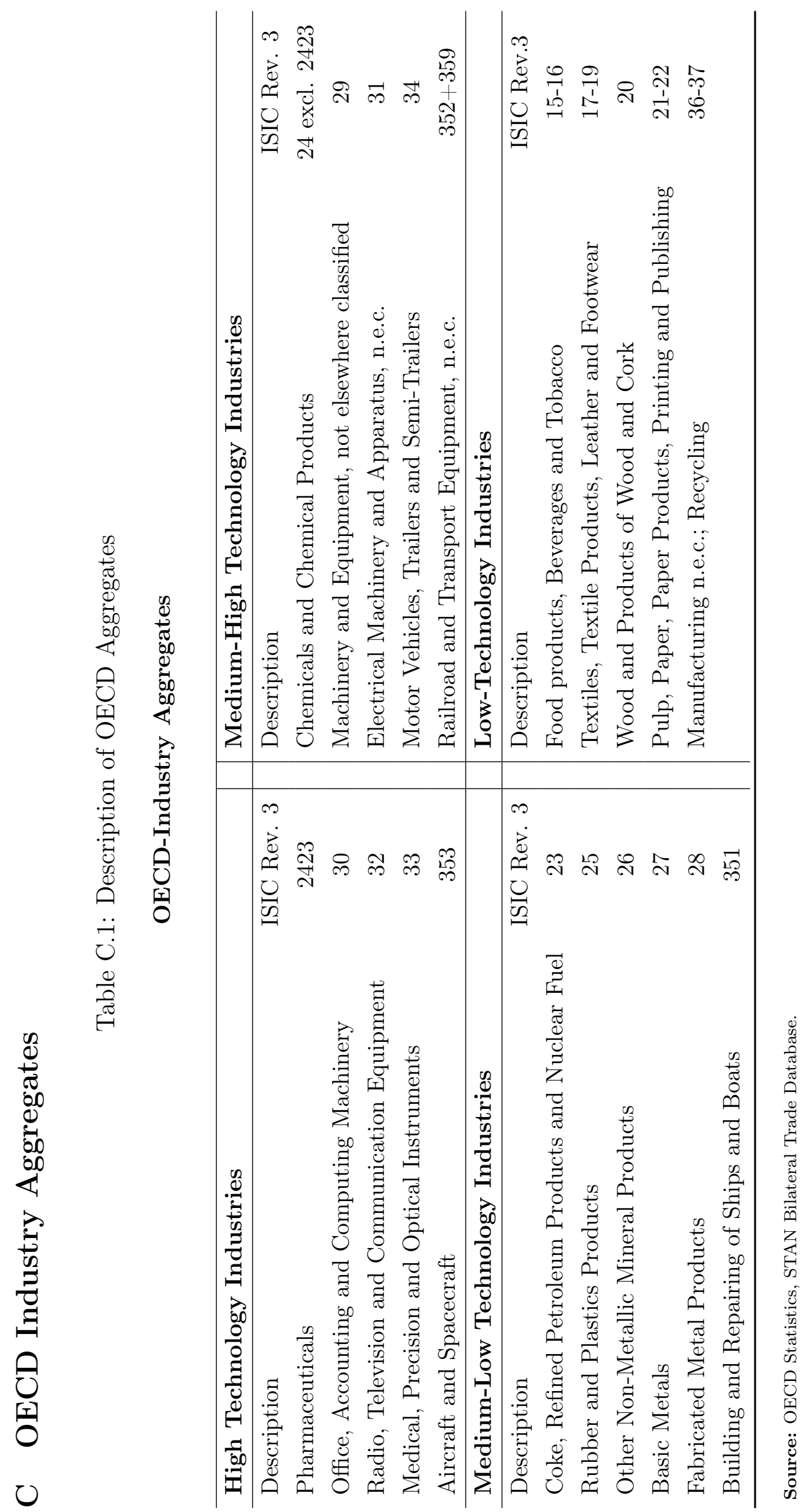




\section{Trade Barrier Measures}

Table D.1: Baseline scenario: Ad-valorem trade barriers

\begin{tabular}{|c|c|c|c|c|c|c|}
\hline & \multicolumn{5}{|c|}{ Importer } \\
\hline & & Japan & $\mathrm{EU}$ & $\mathrm{Ch}+\mathrm{A}$ & NAFTA & RoW \\
\hline \multirow{5}{*}{ 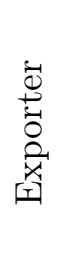 } & Japan & & $69.8 \%$ & $45.6 \%$ & $24.1 \%$ & $48.6 \%$ \\
\hline & $\mathrm{EU}$ & $118.3 \%$ & & $80.5 \%$ & $30.9 \%$ & $39.4 \%$ \\
\hline & $\mathrm{Ch}+\mathrm{A}$ & $46.6 \%$ & $36.4 \%$ & & $5.4 \%$ & $25.0 \%$ \\
\hline & NAFTA & $168.5 \%$ & $125.1 \%$ & $139.9 \%$ & & $111.5 \%$ \\
\hline & RoW & $73.4 \%$ & $40.8 \%$ & $49.1 \%$ & $23.1 \%$ & \\
\hline
\end{tabular}

Notes: This table shows bilateral ad-valorem trade barriers between regions in the baseline scenario, which we obtain by calibrating our model to observed export shares. Each exporter is characterized by a row and each importer is characterized by a column.

Table D.2: Tariff scenario: Ad-valorem trade barriers

\begin{tabular}{|c|c|c|c|c|c|c|}
\hline & \multicolumn{5}{|c|}{ Importer } \\
\hline & & Japan & $\mathrm{EU}$ & $\mathrm{Ch}+\mathrm{A}$ & NAFTA & RoW \\
\hline \multirow{5}{*}{ 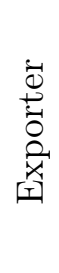 } & Japan & & $67.35 \%$ & $45.6 \%$ & $24.1 \%$ & $48.6 \%$ \\
\hline & $\mathrm{EU}$ & $116.4 \%$ & & $80.5 \%$ & $30.9 \%$ & $39.4 \%$ \\
\hline & $\mathrm{Ch}+\mathrm{A}$ & $46.6 \%$ & $36.4 \%$ & & $5.4 \%$ & $25.0 \%$ \\
\hline & NAFTA & $168.5 \%$ & $125.1 \%$ & $139.9 \%$ & & $111.5 \%$ \\
\hline & RoW & $73.4 \%$ & $40.8 \%$ & $49.1 \%$ & $23.1 \%$ & \\
\hline
\end{tabular}

Notes: This table shows bilateral ad-valorem trade barriers between regions in the tariff scenario. Each exporter is characterized by a row and each importer is characterized by a column.

Table D.3: NTB scenario: Ad-valorem trade barriers

\begin{tabular}{|c|c|c|c|c|c|c|}
\hline & \multicolumn{5}{|c|}{ Importer } \\
\hline & & Japan & $\mathrm{EU}$ & $\mathrm{Ch}+\mathrm{A}$ & NAFTA & RoW \\
\hline \multirow{5}{*}{ 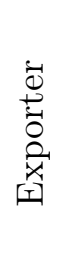 } & Japan & & $51.2 \%$ & $45.6 \%$ & $24.1 \%$ & $48.6 \%$ \\
\hline & $\mathrm{EU}$ & $99.7 \%$ & & $80.5 \%$ & $30.9 \%$ & $39.4 \%$ \\
\hline & $\mathrm{Ch}+\mathrm{A}$ & $46.6 \%$ & $36.4 \%$ & & $5.4 \%$ & $25.0 \%$ \\
\hline & NAFTA & $168.5 \%$ & $125.1 \%$ & $139.9 \%$ & & $111.5 \%$ \\
\hline & RoW & $73.4 \%$ & $40.8 \%$ & $49.1 \%$ & $23.1 \%$ & \\
\hline
\end{tabular}

Notes: This table shows bilateral ad-valorem trade barriers between regions in the comprehensive liberalization scenario. Each exporter is characterized by a row and each importer is characterized by a column. 